ISSN 2597- 6052

\title{
Analisis Pelayanan Kesehatan Ibu dan Anak di Pulau Beeng Laut
}

\author{
Analysis of Maternal and Childs Health Service in Beeng Laut Island
}

Dhito Dwi Pramardika

Politeknik Negeri Nusa Utara

Email :dhitodwi@gmail.com

\begin{abstract}
Abstrak
Pelayanan kesehatan ibu dan anak merupakan pelayanan kesehatan yang bertujuan untuk menurunkan angka morbiditas dan mortalitas pada ibu dan anak. Pada tahun 2017 terdapat 1 kasus angka kematian ibu di pulau Beeng Laut dan tidak adanya fasilitas kesehatan dan tenaga kesehatan disana. Tujuan penelitian adalah untuk menganalisis pelayanan kesehatan ibu dan anak di Pulau Beeng Laut. Penelitian ini merupakan jenis penelitian kualitatif dengan pendekatan studi kasus yang dilakukan dengan menggunakan indepth interview yang dilakukan terhadap 4 partisipan dan dianalisis dengan triangulasi sumber. Hasil pada penelitian ini adalah pelayanan kesehatan ibu dan anak yang dilaksanakan di Pulau Beeng Laut yaitu dilakukan satu kali dalam satu bulan, pelaksanaannya bersamaan dengan kegiatan Posyandu bayi dan balita, rendahnya pemanfaatan pelaksanaan pelayanan kesehatan ibu nifas dan neonatus serta rendahnya pemanfaatan masyarakat terhadap rumah tunggu yang telah difasilitasi Puskesmas dalam mengakses pelayanan kesehatan dan disarankan agar Pemerintah Kabupaten Kepulauan Sangihe dapat menyediakan fasilitas kesehatan dan tenaga kesehatan di Pulau Beeng Laut untuk meningkatkan derajat kesehatan masyarakat di Pulau tersebut terutama kesehatan pada ibu dan anak.
\end{abstract}

Kata Kunci : Pelayanan kesehatan, ibu, anak, pulau beeng laut

\begin{abstract}
Maternal and child health services are health services that aim to reduce morbidity and mortality rates for mothers and children. In 2017 there was 1 case of maternal mortality rate on Beeng Laut island and there were no health facilities and health workers there. The purpose of the study was to analyze maternal and child health services on Beeng Laut Island. This research is a type of qualitative research with a case study approach conducted using in-depth interviews conducted with 4 participants and analyzed with source triangulation. The results of this study are maternal and child health services carried out on Beeng Laut Island, which is conducted once a month, the implementation is in conjunction with the Posyandu for infants and toddlers, the low utilization of the implementation of postpartum and neonatal maternal health services and the low utilization of the community towards waiting houses. the Puskesmas has facilitated access to health services and it is recommended that the Sangihe Islands District Government can provide health facilities and health workers on Beeng Laut Island to improve the health status of the people on the Island especially for maternal and child.
\end{abstract}

Keywords : Health services, mother, child, beeng laut island 


\section{PENDAHULUAN}

Tujuan Pembangunan berkelanjutan (SDG's) hingga tahun 2030 pada bidang kesehatan salah satunya yaitu berfokus pada penurunan angka kematian ibu dan bayi. Salah satu upayanya yaitu melalui peningkatan pelayanan kesehatan pada ibu dan anak secara merata di seluruh wilayah Indonesia. Sementara itu, target yang telah ditetapkan berdasarkan SDG's yaitu turunnya angka kematian ibu menjadi 70 kasus per 100.000 kelahiran hidup dan pada angka kematian bayi, target yang ditetapkan sebesar 12 per 1.000 kelahiran hidup, serta menurunnya angka kematian balita sebesar 25 per 1.000 kelahiran hidup (1).

Data saat ini menunjukkan bahwa Indonesia berdasarkan Survei Penduduk Antar Sensus (SUPAS) 2015 masih menempati posisi 305 per 100 ribu kelahiran hidup (2). Sementara Data SDKI (2017) angka kematian neonatal sebesar 15 per 1.000 kelahiran hidup (2). Pada tahun 2018, Sulawesi Utara angka kematian ibu sebanyak 49 kasus dan angka kematian bayi sebanyak 135 kasus (3). Sementara data di Kabupaten Kepulauan Sangihe pada tahun 2018 angka kematian bayi sebanyak 6 kasus, dan pada tahun 2019 hingga bulan juni angka kematian bayi sebanyak 5 kasus (2). Untuk data kematian ibu pada tahun 2017 sebanyak 2 orang yaitu di Puskesmas Enemawira dan Puskesmas Salurang (4).

Salah satu kejadian kematian ibu yang terjadi di Puskesmas Salurang yaitu berasal dari Pulau Beeng Laut. Di Pulau Beeng laut terdapat perkampungan yang dihuni sebanyak 49 sebuah Kepala Keluaraga. Pulau ini dapat ditempuh dengan menggunakan perahu sekitar 30 menit dari kampung Salurang. Di perkampungan ini tidak tersedia fasilitas pelayanan kesehatan dan tenaga kesehatan.

Berdasarkan hal tersebut, penelitian ini bertujuan untuk menganalisis pelayanan kesehatan ibu dan anak di Pulau Beeng Laut.

\section{METODE}

Desain dari penelitian ini adalah penelitian kualitatif yang merupakan sebuah studi kasus berdasarkan permasalahan yang dialami oleh masyarakat di Pulau Beeng Laut. Penelitian ini dilakukan dengan menggunakan indepth interview atau wawancara mendalam pada tanggal bulan Juli tahun 2019 di Pulau Beeng Laut Kabupaten Kepulauan Sangihe.

Dalam penelitian ini, partisipan dipilih dengan menggunakan purposive sampling yaitu terdiri dari Kapitalaung atau Kepala Desa, 1 orang Kader Posyandu, dan 2 orang ibu di Pulau Beeng Laut. Metode pengumpulan data yang digunakan dengan tiga cara yaitu melalui wawancara, observasi dan dokumen. Teknik analisis pada penelitian kualitatif adalah reduksi data dan peyajian data.kemudian akan dianalisis dan dilakukan validasi dengan menggunakan triangulasi sumber [6]

\section{HASIL}

Kabupaten Kepulauan Sangihe merupakan salah satu dari wilayah yang berada pada Provinsi Sulawesi Utara dengan luas wilayah darat sebesar 10 persen dan wilayah laut sebesar 90 persen. Kabupaten ini diapit oleh Laut Maluku dan Samudera Pasifik. Salah satu kecamatan pada Kabupaten ini yaitu Kecamatan Tabukan Selatan Tengah, dengan ibukota kecamatan yang berada di Kampung Salurang. Di Kampung Saluran ini terdapat Puskesmas yang bernama Puskesmas Salurang dan salah satu wilayah kerjanya yaitu Kampung Beeng Laut. Kampung ini memiliki jumlah penduduk sebanyak $49 \mathrm{KK}$.

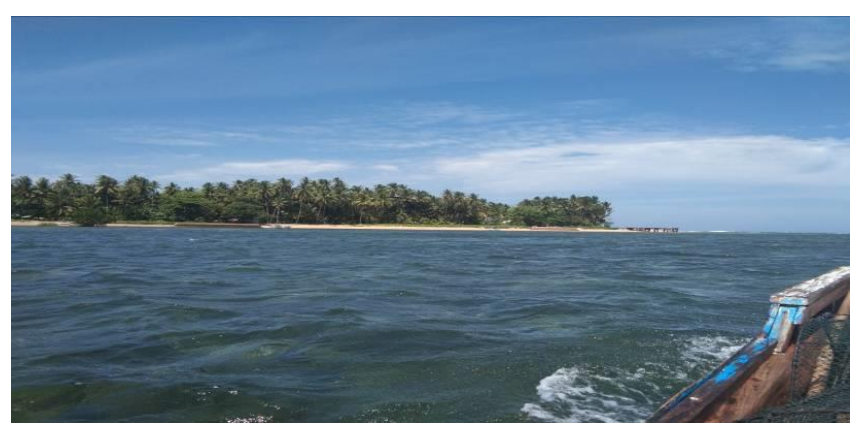

Gambar 1. Pulau Beeng Laut

\section{Pelayanan Kesehatan Ibu Hamil}

Berdasarkan hasil wawancara kepada partisipan dapat diketahui bahwa pelayanan kesehatan ibu hamil dilakukan oleh petugas Puskesmas Salurang sebulan sekali, bersamaan dengan kegiatan Posyandu. Kegiatan tersebut disertai juga pelayanan kesehatan umum lainnya. petugas kesehatan yang melayani dari Puskesmas Salurang 8 sampai dengan 12 orang sekali datang. Hal itu sesuai dengan kutipan wawancara pada partisipan ibu berikut ini :

Kutipan 1

"iya, pelayanan kesehatan ibu dan anak cuma sekali dalam sebulan, bersamaan dengan kegiatan Posyandu, terkadang juga kami pergi periksa ke puskesmas. Kalo periksa sudah lebih dari 4 kali pak selama hamil."

(A, 35 th)

Pernyataan tersebut juga diperkuat dari kutipan dari partisipan kader dan partisipan Kapitalaung berikut ini :

Kutipan 2

"pelayanan Posyandu tiap bulan sekali pak, biasanya melayani semuanya. Ada petugas khusus posyandu, ada juga petugas yang melayani kesehatan 
umum lainnya. mereka membawa perlengkapan lengkap termasuk obat, vaksin, tensi dan stetoskop"

(K, 47 th)

Kutipan 3

"mereka biasanya menghubungi saya melalui hape, kemudian kami jemput dengan perahu. Mereka lebih senang kesini karena biasanya siapapun tamunya, kami akan memberikan jamuan makan, makanya kalo datang itu bisa 8 sampai 12 orang ”

$(\mathrm{KP}, 40$ th)

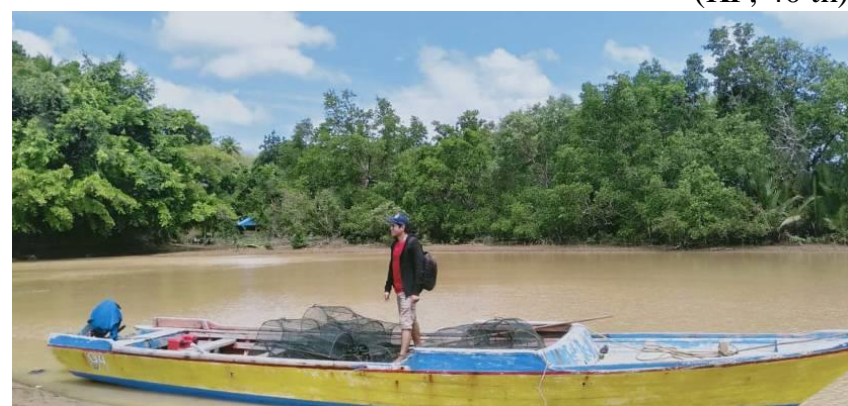

Gambar 2. Sarana Transportasi Masyarakat Beeng Laut Berupa Perahu

\section{Pelayanan kesehatan ibu bersalin}

Berdasarkan hasil wawancara kepada partisipan dapat diketahui bahwa pelayanan kesehatan ibu bersalin masyarakat di Pulau Beeng Laut yaitu mereka bersalin di fasilitas kesehatan dan dilakukan oleh tenaga kesehatan. Hal itu sesuai dengan kutipan wawancara pada partisipan ibu berikut ini :

Kutipan 4

"melahirkannya normal di puskesmas Salurang dengan ibu bidan"

$(\mathrm{A}, 35$ th)

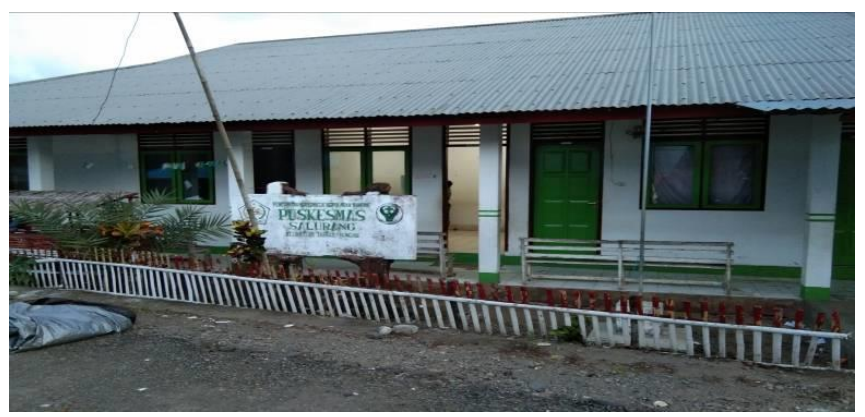

Gambar 3. Puskesmas Salurang

Pernyataan tersebut juga diperkuat dari kutipan dari partisipan Kapitalaung berikut ini :

Kutipan 5

"dua tahun ini sejak dukunnya pergi ke manado melihat keluarganya, masyarakat disini sudah melahirkan di Puskesmas Salurang dengan bidan disana. Untuk pelayanan ibu bersalin, sebenarnya Puskesmas Salurang sudah menyediakan rumah tunggu persalinan yang disewa sekitar delapan jutaan per tahun berupa satu buah kamar yang berada pada salah satu rumah warga dan terletak di depan
Puskesmas. Warga dapat memanfaatkan fasilitas tersebut secara gratis"

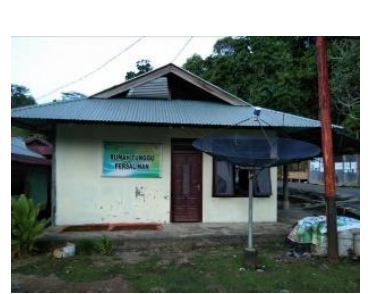

(KP, 40 th)

Gambar 4. Rumah Tunggu Persalinan di Kampung Salurang

Pelayanan kesehatan ibu nifas

Berdasarkan hasil wawancara kepada partisipan dapat diketahui bahwa pelayanan kesehatan ibu nifas masyarakat di Pulau Beeng Laut yaitu mereka tidak melakukan kunjungan nifas dikarenakan kurangnya pengetahuan mereka terhadap pelayanan nifas. Mereka lebih fokus terhadap pelayanan bayi mereka pada saat setelah melahirkan. Hal itu sesuai dengan kutipan wawancara pada partisipan ibu berikut ini :

Kutipan 6

"setelah melahirkan nya nda periksa lagi, paling periksa kita punya anak ke posyandu”

$(\mathrm{A}, 35$ th $)$

Pernyataan tersebut juga diperkuat dari kutipan dari partisipan kader berikut ini :

Kutipan 7

"setelah melahirkan mereka tidak periksa, yang diperiksa hanya bayinya untuk ditimbang di posyandu"

$(\mathrm{K}, 47 \mathrm{th})$

\section{Pelayanan kesehatan Neonatus}

Berdasarkan hasil wawancara kepada partisipan dapat diketahui bahwa pelayanan kesehatan neonatus masyarakat di Pulau Beeng Laut yaitu mereka rajin melakukan kunjungan ke posyandu untuk memeriksakan anak mereka termasuk pemberian ASI Ekslusif dan imunisasi. Hal itu sesuai dengan kutipan wawancara pada partisipan ibu berikut ini :

Kutipan 8

"setelah melahirkan nya nda periksa lagi, paling periksa kita punya anak ke posyandu”

(A, 35 th)

Pernyataan tersebut juga diperkuat dari kutipan dari partisipan kader berikut ini :

Kutipan 9

"setelah melahirkan mereka tidak periksa, yang diperiksa hanya bayinya untuk ditimbang di posyandu, pemberian ASI Ekslusif dan vaksin di posyandu"

$(\mathrm{K}, 47 \mathrm{th})$

Pelayanan Kesehatan Balita dan Anak Pra Sekolah Berdasarkan hasil wawancara kepada partisipan dapat diketahui bahwa pelayanan kesehatan 
balita dan anak pra sekolah bersamaan dengan kegiatan Posyandu. Kegiatan yang didapatkan berupa pemberian MP-ASI, pemberian vitamin A dan kegiatan deteksi dini tumbuh kembang anak di Posyandu. Penyakit yang paling banyak dikeluhkan masyarakat mengenai kesehatan anak mereka yaitu ISPA dan diare. Hal itu sesuai dengan kutipan wawancara pada partisipan ibu berikut ini :

Kutipan 10

"biasa periksa anak ke posyandu, nanti kita punya anak ditimbang dan diukur tingginya, kadang juga dikasih vitamin dan disuntik"

Pernyataan tersebut juga diperkuat dari kutipan dari partisipan kader berikut ini :

Kutipan 11

"pelayanan kesehatan balita gabung dengan posyandu seperti pemberian vitamin A dua kali dalam setahun, penimbangan dan pengukuran, deteksi dini tumbuh kembang anak yang dilakukan oleh petugas puskesmas. Kami juga mendapatkan bantuan MP-ASI yang kami bagikan kepada balita yang berada di bawah garis merah. Penyakit yang paling banyak dikeluhkan yaitu batuk pilek dan diare. Di sini juga ada balita tidak mau vaksin"

(K, 47 th)

\section{Pelayanan Kesehatan Keluarga Berencana}

Berdasarkan hasil wawancara kepada partisipan dapat diketahui bahwa pelayanan keluarga berencana masyarakat di Pulau Beeng Laut yaitu penggunaan kontrasepsi suntik 3 bulanan paling banyak digunakan wanita usia subur di pulau tersebut. Masyarakat Pulau Beeng Laut sudah menerapkan program Keluarga Berencana dikarenakan penyuluhan yang mereka terima dari petugas kesehatan di Puskesmas Salurang. Dan jumlah kehamilan dan kelahiran di Pulau Beeng Laut yang rendah merupakan bukti nyata dari pelayanan keluarga berencana ini. Hal itu sesuai dengan kutipan wawancara pada partisipan ibu berikut ini :

Kutipan 12

" $k b$ yang digunakan $k b$ suntik pak, Cuma ya ini pak, saya sudah lewat masa suntiknya namun hingga sekarang belum ada menstruasi tapi tidak juga hamil, konsul dengan orang puskesmas katanya memang seperti itu, efek dari kb ini katanya pak."

(MS, 38 th)

Pernyataan tersebut juga diperkuat dari kutipan dari partisipan kader berikut ini :

Kutipan 13

"WUS disini hampir semuanya pake kb suntik pak, biasa mereka suntiknya di Salurang"

(K, 47 th)
Berdasarkan hasil wawancara kepada partisipan dapat diketahui bahwa kejadian itu terjadi pada tahun 2017 dikarenakan terlambat mendapatkan pertolongan yang adekuat, karena sudah terlambat sampai sehingga dalam penanganannya pun terlambat juga. Kondisi ibu sudah makin melemah, ditambah lagi bila sesampainya disana, fasilitasnya kurang lengkap atau tenaga medisnya kurang. Akhirnya benar-benar terlambat ditangani. Hal itu sesuai dengan kutipan wawancara pada partisipan utama berikut ini :

Kutipan 14

"dulu, dua tahun yang lalu pak, ada ibu hamil meninggal, usianya belum sampai 30 tahun itu pak"

(MS, 38 th)

Hal tersebut diperkuat dengan kutipan wawancara pada partisipan kunci berikut ini : Kutipan 15

"kejadiannya dua tahun yang lalu pak, saat itu ibu hamilnya saya yang bawa naik perahu pada malam hari, angin kencang dan gelombang dari Beeng Laut ke Puskesmas Salurang namun akhirnya meninggal setelah melahirkan pak di Puskesmas"

(KP, 40 th)

\section{PEMBAHASAN}

Berdasarkan hasil penelitian melalui indepth interview maka didapatkan beberapa permasalahan sebagai berikut :

\section{Pelayanan kesehatan ibu hamil}

Berdasarkan hasil penelitian diketahui bahwa untuk pelayanan kesehatan pada ibu hamil di Pulau Beeng Laut sudah cukup baik, terutama dalam peran dari sebuah posyandu sebagai kegiatan Upaya Kesehatan Bersumberdaya Masyarakat (UKBM) yang telah melaksanakan fungsinya yang tidak hanya pelayanan bagi bayi dan balita namun juga pada ibu hamil. Hal ini sesuai dengan sasaran yang diungkapkan dalam kegiatan posyandu adalah Semua anggota masyarakat yang membutuhkan pelayanan kesehatan dasar yang ada di Posyandu terutama bayi dan anak balita, ibu hamil, ibu nifas dan ibu menyusui, pasangan usia subur dan pengasuh anak (5).

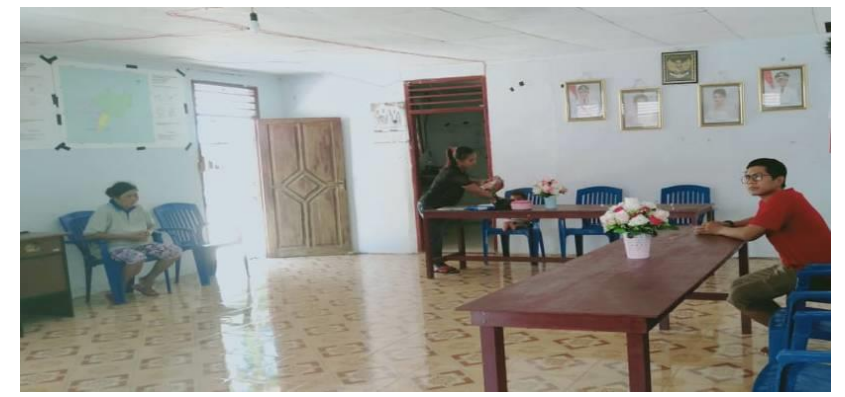

Gambar 5. Posyandu Di Pulau Beeng Laut

\section{Kasus kematian ibu hamil}


Pelaksanaan posyandu yang rutin dilaksanakan setiap bulan juga meningkatkan cakupan dari kunjungan K1 dan K4 pada ibu hamil. Cakupan dari indikator tersebut berperan dalam kegiatan monitoring dan evaluasi untuk memperlihatkan akses pelayanan kesehatan terhadap ibu hamil dan tingkat kepatuhan ibu hamil dalam memeriksakan kehamilannya ke tenaga kesehatan (6).

\section{Pelayanan kesehatan ibu bersalin}

Berdasarkan hasil penelitian diketahui bahwa ibu bersalin di Pulau Beeng Laut lebih memilih melaksanakan persalinan pada tenaga kesehatan dan di fasilitas kesehatan meskipun jarak dan akses yang jauh. Pertolongan persalinan tenaga kesehatan terlatih merupakan salah satu cara efektif untuk menurunkan kematian ibu. Namun, hal ini belum sesuai target pemerintah yang menyatakan bahwa satu bidan untuk satu desa karena persalinan bisa setiap saat terjadi baik siang maupun malam, sehingga keberadaan bidan di tempat memudahkan untuk meminta pertolongan yang cepat dan terjangkau (7).

\section{Pelayanan kesehatan ibu nifas}

Berdasarkan hasil penelitian diketahui bahwa kurangnya pemanfaatan pelayanan kesehatan ibu nifas pada masyarakat Pulau Beeng laut. Hal itu dikarenakan kurangnya pemahaman terhadap pentingnya pemeriksaan kesehatan di masa nifas. Pemahaman disini berupa pengetahuan seseorang yang kemudian akan meningkatkan kesadaran. Hal itu sesuai dengan pernyataan Notoatmojdo (2012) yang menyatakan bahwa pengetahuan atau kognitif merupakan domain yang sangat penting dalam membentuk tindakan seseorang (over behaviour) karena dari pengalaman penelitian terbukti bahwa perihal yang didasari oleh pengetahuan lebih langgeng dari pada perilaku yang tidak didasari oleh pengetahuan (8).

\section{Pelayanan kesehatan neonatus}

Berdasarkan hasil penelitian diketahui bahwa pelayanan kesehatan neonatus di pulau Beeng Laut yaitu dilakukan pada saat pelaksanaan posyandu. Seharusnya masa neonatus tersebut pelayanan kesehatan paling minimal dilakukan sebanyak 3 kali kunjungan yaitu 6-48 jam postpartum, hari ke-3 sampai dengan hari ke-7 postpartum, dan hari ke-8 sampai dengan hari ke-28 postpartum (6). Namun dikarenakan akses fasilitas kesehatan dan ketiadaan tenaga kesehatan di Pulau Beeng Laut maka orang tua dari neonatus tersebut melewatkan waktu-waktu pelayanan kesehatan neonatus tersebut.

\section{Pelayanan kesehatan balita dan anak pra sekolah}

Berdasarkan hasil penelitian diketahui bahwa pelayanan kesehatan balita dan anak pra sekolah sama seperti pelayanan kesehatan lainnya di Pulau Beeng Laut bahwa pelaksanaannya bersamaan dengan kegiatan posyandu. Pelayanan kesehatan yang diberikan berupa deteksi dini tumbuh kembang namun hanya berupa pengukuran fisik seperti berat badan, tinggi badan dan lingkar kepala. Sedangkan dalam aspek pemantauan perkembangan hal tersebut tidak dilakukan, mengingat hal tersebut merupakan hal yang penting. Setiap anak tidak akan bisa melewati satu tahap perkembangan sebelum ia melewati tahapan sebelumnya. Sebagai contoh, seorang anak tidak akan bisa berjalan sebelum ia bisa berdiri. Seorang anak tidak akan bisa berdiri jika pertumbuhan kaki dan bagian tubuh lainyang terkait dengan fungsi berdiri anak terhambat. Karena itu perkembangan awal ini merupakan masa kritis karena akan menentukan perkembangan selanjutnya (9).

\section{Pelayanan kesehatan keluarga berencana}

Berdasarkan hasil penelitian diketahui bahwa pelayanan kesehatan keluarga berencana sudah cukup baik dikarenakan pemerintah Kabupaten Kepulauan Sangihe yang berkomitmen terhadap program dari keluarga berencana sehingga di Pulau Beeng Laut-pun masyarakatnya berkomitmen terhadap program tersebut. Hal ini dibuktikan dengan Kabupaten Kepulauan Sangihe yang mendapatkan penghargaan Manggala Karya kencana oleh Menteri koordinator Pembangunan manusia dan kebudayaan Puan Maharani (10).

Pemilihan kb suntik 3 bulan lebih disukai dikarenakan jangka waktu dan kemudahan dalam menggunakannya menjadi alasan utama. Namun juga mempunyai beberapa efek yang dialami dan disampaiakan dari hasil indepth interview oleh pasangan usia subur di Pulau Beeng Laut. Hal ini sesuai dengan pendapat yang menyatakan bahwa suntik kb 3 bulan mempunyai efek samping gangguan menstruasi, kenaikan berat badan, kolesterol, tulang rapuh, penurunan libido (10).

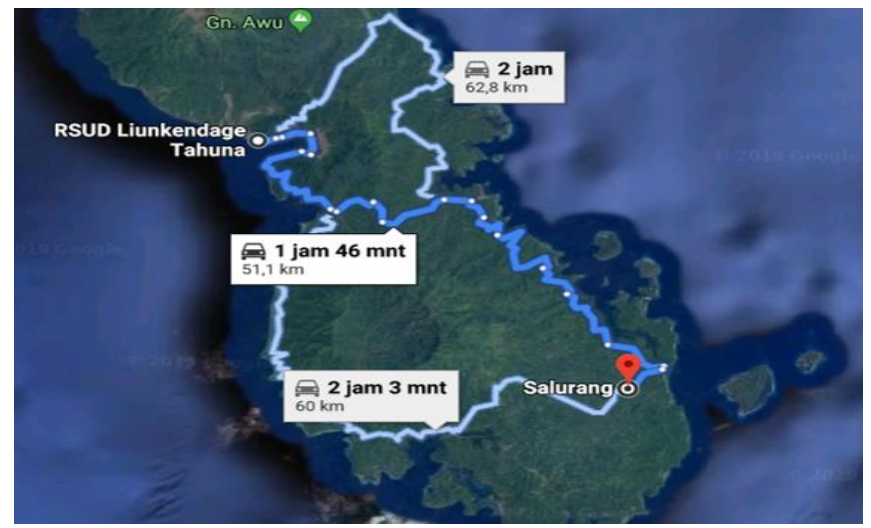

Gambar 6. Jarak Fasilitas Kesehatan dengan Pulau Beeng Laut

Berdasarkan hasil penelitian diketahui bahwa pada tahun 2017 terdapat satu kasus kematian ibu 
hamil. Hal itu dikarenakan faktor akses fasilitas kesehatan yang jauh dan berbahaya yaitu jarak dari Pulau Beeng Laut ke Puskesmas Salurang ditempuh selama 45 menit menggunakan perahu dan tergantung dari ombak dan cuaca. Ketidakadaan petugas kesehatan juga menjadi suatu persoalan yang mendasar karena untuk meningkatkan pelayanan kesehatan ke dua faktor tersebut merupakan hal yang paling utama. Hal itu sesuai dengan utilitas pelayanan kesehatan yang menjelaskan bahwa keinginan seseorang untuk memanfaatkan pelayanan kesehatan juga ditentukan oleh faktor pendukung yakni salah satunya adalah jarak atau aksesibilitas layanan kesahatan (11).

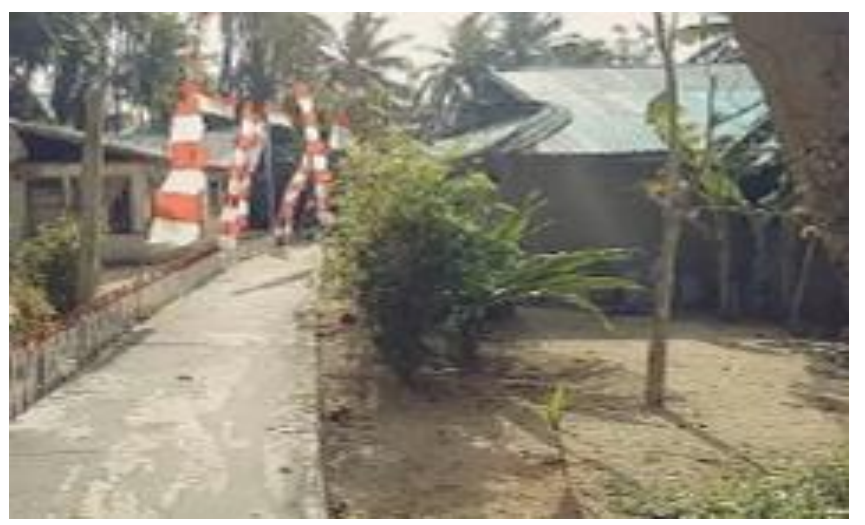

Gambar 7. Pemukiman di Pulau Beeng Laut

Akses pelayanan kesehatan tersebut dikarenakan tidak adanya fasilitas kesehatan yang tersedia di Pulau Beeng Laut. Padahal dari segi sarana dan pra sarana pulau tersebut sudah memenuhi seperti tersedianya air bersih dan listrik yang menggunakan tenaga surya. Hal ini masih belum sesuai dengan program rencana pembangunan jangka menengah nasional yang dibuat pemerintah 2015-2019 yang bertujuan untuk meningkatkan akses pelayanan kesehatan dasar dan pemenuhan sumber daya tenaga kesehatan yang berkualitas. Kebijakan ini merupakan salah satu arah kebijakan pembagunan kesehatan terutama di daerah tertinggal, terpencil dan kepulauan (DTPK) (12).

Akibat dari tidak terpenuhinya 2 faktor tersebut maka dapat meningkatkan angka kesakitan dan kematian pada suatu masyarakat. Kemudian dari tingkat pendidikan masyarakat Pulau Beeng Laut yang rendah berakibat pada pemahaman dan pengetahuan mengenai tanda bahaya kehamilan serta rendahnya pemanfaatan rumah tunggu persalinan yang telah disediakan oleh pihak Puskesmas Salurang.

Status pendidikan sangat erat kaitannya dengan kesadaran dan pengetahuan seseorang, sehingga status pendidikan memiliki pengaruh yang signifikan terhadap pemanfaatan pelayanan kesehatan. Biasanya masyarakat yang berpendidikan rendah, kurang memiliki kesadaran dan pengetahuan yang baik tentang manfaat pelayanan pelayanan kesehatan (13).
Walaupun demikian, tingkat pendidikan juga dapat mempengaruhi pemanfaatan pelayanan kesehatan dikarenakan dengan pendidikan yang tinggi maka seseorang akan mempunyai pengetahuan yang tinggi dibandingkan dengan seseorang yang berpendidikan rendah. Kurangnya pengetahuan dan pemahaman tersebut berdampak pada terlambat mengambil keputusan, sehingga terlambat untuk mendapat penanganan kemudian terlambat sampai ke tempat rujukan karena kendala transportasi dan terlambat mendapat penanganan karena terbatasnya sarana dan sumber daya manusia (6).

\section{KESIMPULAN}

Pelayanan kesehatan ibu dan anak di Pulau Beeng Laut kurang efektif karena hanya dilaksanakan sebulan sekali bertepatan dengan kegiatan Posyandu dan jika ingin mengakses pelayanan kesehatan maka masyarakat pulau Beeng Laut harus menempuh jarak yang jauh dikarenakan ketiadaaan sarana dan pra sarana kesehatan serta petugas kesehatan. Disarankan agar Pemerintah Kabupaten Kepulauan Sangihe dapat menyediakan fasilitas kesehatan dan tenaga kesehatan di Pulau Beeng Laut untuk meningkatkan derajat kesehatan masyarakat di Pulau tersebut.

\section{DAFTAR PUSTAKA}

1. Kementerian Pemberdayaan Perempuan dan Perlindungan Anak. Profil anak indonesia 2018. Jakarta CV Miftahur Rizky. 2018;4-6.

2. Dinas Kesehatan Kabupaten Kepulauan. Profil Kesehatan Kabupaten Kepulauan. Kesehat Kabupaten Kepul. 2018;

3. Penelitian B, Kesehatan P, RI KK. Hasil utama riskesdas 2018. Jakarta Kemenkes RI. 2018;

4. Kesehatan Kabupaten Kepulauan. Profil Kesehatan Kabupaten Kepulauan 2018. 2017;

5. RI PPKKK. Ayo ke Posyandu Setiap Bulan. Jakarta Kementrian Kesehat RI. 2012;

6. Kementrian Kesehatan RI. Buku Ajar Kesehatan Ibu dan Anak. Jakarta Pus Pendidik dan Pelatih Tenaga Kesehat. 2015;

7. Alkaff Z. Paradigma Baru Pelayanan Kesehatan Reproduksi Bagi Ibu. In: Makalah, Disampaikan Pada Seminar Kompetensi Bidan Profesional, FK-UGM, Yogyakarta. 2001.

8. Notoatmodjo S. Promosi kesehatan dan ilmu perilaku. Jakarta: Rineka Cipta. 2007;20.

9. Chamidah AN. Deteksi dini gangguan pertumbuhan dan perkembangan anak. J Pendidik khusus. 2009;5(2):83-93.

10. Raikhani A, Yunas NS, Ratnasari L, Hariastuti I. Analisa Kontribusi Program Kampung KB dalam Upaya Peningkatan Program KKBPK di Kab. Jombang, Provinsi Jawa Timur. J Ilm Kebidanan (Scientific J Midwifery). 
2018;4(2):101-13.

11. Green LW, Marshall W. Kreuter: Health Program Planning: An educational and ecological approach. MC Graw Hill co; 2005.

12. Kesehatan K. Rencana strategis kementerian kesehatan. Jakarta Kementeri Kesehat. 2015;

13. Rumengan DSS, Kandou JMLUGD. FaktorFaktor yang Berhubungan dengan Pemanfaatan Pelayanan Kesehatan Pada Peserta BPJS Kesehatan di Puskesmas Paniki Bawah Kecamatan Mapanget Kota Manado. Jkimu. 2015; 